\title{
Ruegeria faecimaris sp. nov., isolated from a tidal flat sediment
}

\author{
Ki-Hoon Oh, Yong-Taek Jung, Tae-Kwang Oh and Jung-Hoon Yoon
}

Correspondence

Jung-Hoon Yoon

jhyoon@kribb.re.kr
Korea Research Institute of Bioscience and Biotechnology (KRIBB), PO Box 115, Yusong, Taejon, Republic of Korea

\begin{abstract}
A Gram-negative-staining, non-motile and rod-shaped bacterial strain, $\mathrm{HD}-28^{\top}$, was isolated from a tidal flat of the Yellow Sea, Korea. Strain HD-28 ${ }^{\top}$ grew optimally at $\mathrm{pH} 7.0-8.0$ and $30{ }^{\circ} \mathrm{C}$ in the presence of $2-3 \%(\mathrm{w} / \mathrm{v}) \mathrm{NaCl}$. Phylogenetic analyses based on 16S rRNA gene sequences showed that strain HD-28 ${ }^{\top}$ was most closely related to species of the genus Ruegeria and exhibited 95.5-96.9\% 16S rRNA gene sequence similarity to the type strains of Ruegeria species. A neighbour-joining phylogenetic tree based on gyrB gene sequences also showed that strain HD-28 ${ }^{\top}$ fell within the cluster comprising recognized species of the genus Ruegeria, showing 77.5-83.9\% sequence similarity. Strain $\mathrm{HD}^{-28^{\top}}$ contained $\mathrm{Q}-10$ as the predominant ubiquinone and $\mathrm{C}_{18: 1} \omega 7 \mathrm{c}$ as the major fatty acid. The major polar lipids detected in strain HD-28 were phosphatidylcholine, phosphatidylglycerol, an unidentified aminolipid and two unidentified lipids. The DNA G $+\mathrm{C}$ content was 57.9 mol\%. Differential phenotypic properties, together with phylogenetic distinctiveness, demonstrated that strain $\mathrm{HD}^{-28^{\top}}$ could be distinguished from recognized species of the genus Ruegeria. On the basis of phenotypic, chemotaxonomic and phylogenetic data, strain $\mathrm{HD}-28^{\top}$ is considered to represent a novel species of the genus Ruegeria, for which the name Ruegeria faecimaris sp. nov. is proposed. The type strain is HD- $28^{\top}$ $\left(=\right.$ KCTC $23044^{\top}=$ CCUG $\left.58878^{\top}\right)$.
\end{abstract}

The genus Ruegeria was created by Uchino et al. (1998) through the reclassification of Agrobacterium atlanticum, Agrobacterium gelatinovorum and Roseobacter algicola as Ruegeria atlantica, Ruegeria gelatinovorans and Ruegeria algicola, respectively. Later, Ruegeria gelatinovorans and Ruegeria algicola were reclassified as Thalassobius gelatinovorus (Arahal et al., 2005, 2006) and as a member of a novel genus as Marinovum algicola (Martens et al., 2006), respectively. More recently, two species of the genus Silicibacter, Silicibacter lacuscaerulensis and Silicibacter pomeroyi, were reclassified as members of the genus Ruegeria (Yi et al., 2007). In addition, three further species of the genus Ruegeria have also been described recently: Ruegeria mobilis (Muramatsu et al., 2007), Ruegeria pelagia (Lee et al., 2007) and Ruegeria scottomollicae (Vandecandelaere et al., 2008). However, it has recently been suggested that Ruegeria pelagia is a later heterotypic synonym of Ruegeria mobilis (Lai et al., 2010). In this study, a novel bacterial strain, designated $\mathrm{HD}-28^{\mathrm{T}}$, which was isolated from a tidal flat off Hwang-do in the Yellow Sea, Korea, is described. Comparative $16 \mathrm{~S}$ rRNA gene sequence analysis indicated that strain $\mathrm{HD}-28^{\mathrm{T}}$ was

The GenBank/EMBL/DDBJ accession number for the $16 \mathrm{~S}$ rRNA gene sequence of strain $\mathrm{HD}-28^{\top}$ is GU057915. The accession numbers for the gyrB gene sequences of strain $\mathrm{HD}-28^{\top}$ and Ruegeria scottomollicae CCUG $55858^{\top}$ are GU057916 and GU057917, respectively. phylogenetically closely related to the genus Ruegeria. The aim of the present study was to determine the exact taxonomic position of strain $\mathrm{HD}-28^{\mathrm{T}}$ by using a polyphasic approach that included determination of phenotypic properties and detailed phylogenetic investigations based on 16S rRNA and DNA gyrase B subunit $(g y r B)$ gene sequences.

Strain HD- $28^{\mathrm{T}}$ was isolated by means of the standard dilution plating technique at $25{ }^{\circ} \mathrm{C}$ on marine agar 2216 (MA; Difco). The type strains of six species of the genus Ruegeria were used as reference strains for phenotypic characterization and fatty acid analysis. Ruegeria atlantica KCTC $12424^{\mathrm{T}}$ and Ruegeria lacuscaerulensis KCTC $2953^{\mathrm{T}}$ were obtained from the Korean Collection for Type Cultures (Taejon, Republic of Korea). Ruegeria mobilis CIP $109181^{\mathrm{T}}$ was obtained from the Collection de l'Institut Pasteur (Paris, France). Ruegeria pomeroyi DSM $15171^{\mathrm{T}}$ was obtained from the Deutsche Sammlung von Mikroorganismen and Zellkulturen (Braunschweig, Germany). Ruegeria scottomollicae CCUG $55858^{\mathrm{T}}$ was obtained from the Culture Collection of the University of Göteborg (Göteborg, Sweden).

The morphological, physiological and biochemical characteristics of strain $\mathrm{HD}-28^{\mathrm{T}}$ were investigated using routine cultivation at $30{ }^{\circ} \mathrm{C}$ on MA. Cell morphology was examined by using light (E600; Nikon) and transmission 
Table 1. Differential phenotypic characteristics of strain $\mathrm{HD}-28^{\top}$ and the type strains of other species of the genus Ruegeria

Strains: 1, HD-28 $8^{\mathrm{T}}$; 2, R. atlantica KCTC $12424^{\mathrm{T}}$ (data from Rüger \& Höfle, 1992 and this study); 3, R. lacuscaerulensis KCTC $2953^{\mathrm{T}}$ (Petursdottir \& Kristjansson, 1997 and this study); 4, R. mobilis CIP $109181^{\mathrm{T}}$ (Muramatsu et al., 2007 and this study); 5, R. pomeroyi DSM $15171^{\mathrm{T}}$ (González et al., 2003 and this study); 6, R. scottomollicae CCUG $55858^{\mathrm{T}}$ (Vandecandelaere et al., 2008 and this study). +, Positive; -, negative; w, weakly positive. All strains are positive for activity of oxidase and catalase, utilization of D-glucose, acetate, L-malate and pyruvate (data from this study), acid production from D-ribose (data from this study), and activity of alkaline phosphatase (data from this study). All strains are weakly positive for activity of esterase (C4) (data from this study). All strains are negative for Gram staining, utilization of sucrose, trehalose, maltose, benzoate, salicin, formate and L-glutamate (data from this study), acid production from melezitose, lactose and raffinose (data from this study), and activity of lipase (C14), valine arylamidase, cystine arylamidase, trypsin, $\alpha$-chymotrypsin, naphthol-AS-BI-phosphohydrolase, $\alpha$-galactosidase, $\beta$-glucuronidase, $\alpha$-glucosidase, $\beta$-glucosidase, $N$-acetyl- $\beta$-glucosaminidase, $\alpha$-mannosidase and $\alpha$-fucosidase (data from this study).

\begin{tabular}{|c|c|c|c|c|c|c|}
\hline Optimum growth temperature $\left({ }^{\circ} \mathrm{C}\right)$ & 30 & $20-30$ & 45 & $25-30$ & 30 & 20 \\
\hline \multicolumn{7}{|l|}{ Growth at } \\
\hline $40{ }^{\circ} \mathrm{C}$ & - & - & + & - & + & w \\
\hline Motility & - & - & - & + & + & + \\
\hline Anaerobic growth & - & - & - & $+^{*}$ & - & $-^{*}$ \\
\hline \multicolumn{7}{|l|}{ Hydrolysis of } \\
\hline Aesculin & $\mathrm{w}$ & + & - & + & - & + \\
\hline Xanthine & - & + & + & $-{ }^{*}$ & + & $-{ }^{*}$ \\
\hline Tween 80 & + & - & - & - & - & + \\
\hline \multicolumn{7}{|l|}{ Utilization of ${ }^{*}$} \\
\hline L-Arabinose & - & - & - & + & - & - \\
\hline D-Mannose & + & + & + & + & - & + \\
\hline D-Xylose & - & + & - & + & + & + \\
\hline Citrate & + & + & + & - & + & + \\
\hline Succinate & + & + & + & + & - & + \\
\hline \multicolumn{7}{|l|}{ Acid production from ${ }^{*}$} \\
\hline L-Arabinose & - & + & - & + & - & + \\
\hline Cellobiose & - & + & - & + & - & + \\
\hline D-Fructose & - & - & $\mathrm{w}$ & + & - & + \\
\hline D-Galactose & + & + & - & - & - & + \\
\hline D-Glucose & - & - & - & $\mathrm{w}$ & - & + \\
\hline myo-Inositol & - & - & - & + & - & + \\
\hline Maltose & - & + & - & $\mathrm{w}$ & - & + \\
\hline D-Xylose & - & + & - & $\mathrm{w}$ & + & + \\
\hline \multicolumn{7}{|l|}{ Enzyme activity (API ZYM)* } \\
\hline Esterase lipase (C8) & - & - & $\mathrm{w}$ & - & $\mathrm{w}$ & - \\
\hline Leucine arylamidase & - & $\mathrm{w}$ & $\mathrm{W}$ & $\mathrm{w}$ & + & $\mathrm{w}$ \\
\hline Acid phosphatase & + & - & - & - & - & - \\
\hline$\beta$-Galactosidase & - & - & + & - & - & - \\
\hline DNA G $+C$ content $(\mathrm{mol} \%)$ & 57.9 & 55 & 66.2 & 58.5 & $67.9-68.1$ & 61 \\
\hline
\end{tabular}

${ }^{\star}$ Data from reference type strains obtained in this study. 
electron microscopy (CM-20; Philips). Flagellation was investigated by using transmission electron microscopy with cells (from an exponentially growing culture) negatively stained with $1 \%(\mathrm{w} / \mathrm{v})$ phosphotungstic acid. The Gram reaction was investigated using the bioMérieux Gram stain kit according to the manufacturer's instructions. Growth under anaerobic conditions was determined after incubation in a Forma anaerobic chamber on MA and on MA supplemented with potassium nitrate $(0.1 \%$, w/v), both of which had been prepared anaerobically under a nitrogen atmosphere. Growth at various temperatures (4, $10,20,25,30,37$ and $40{ }^{\circ} \mathrm{C}$ ) was measured on MA. The $\mathrm{pH}$ range for growth was determined in marine broth 2216 (MB; Difco) that was adjusted to various $\mathrm{pH}$ values ( $\mathrm{pH} 4.5-9.5$, using increments of $0.5 \mathrm{pH}$ units) by the addition of $\mathrm{HCl}$ or $\mathrm{Na}_{2} \mathrm{CO}_{3}$. Growth in the absence of $\mathrm{NaCl}$ and in the presence of $0.5,1.0,2.0$ and $3.0 \%(\mathrm{w} / \mathrm{v}) \mathrm{NaCl}$ was investigated in trypticase soy broth prepared according to the formula of the Difco medium except that $\mathrm{NaCl}$ was excluded and $0.45 \%(\mathrm{w} / \mathrm{v}) \mathrm{MgCl}_{2} \cdot 6 \mathrm{H}_{2} \mathrm{O}$ or $0.06 \%(\mathrm{w} / \mathrm{v})$ $\mathrm{KCl}$ were added. Growth at various $\mathrm{NaCl}$ concentrations $(2.0-8.0 \%, \mathrm{w} / \mathrm{v}$, at increments of $1.0 \%)$ was investigated in MB. Catalase and oxidase activities were determined as described by Cowan \& Steel (1965). Hydrolysis of casein, starch, hypoxanthine, L-tyrosine and xanthine was tested on MA, using the substrate concentrations described by Cowan \& Steel (1965). Nitrate reduction and hydrolysis of aesculin, gelatin, Tweens $(20,40,60$ and 80$)$ and urea were investigated as described previously (Lányí, 1987) with the replacement of distilled water by artificial seawater. The artificial seawater contained $\left(1^{-1}\right.$ distilled water): $23.6 \mathrm{~g}$ $\mathrm{NaCl}, \quad 0.64 \mathrm{~g} \mathrm{KCl}, \quad 4.53 \mathrm{~g} \quad \mathrm{MgCl}_{2} .6 \mathrm{H}_{2} \mathrm{O}, \quad 5.94 \mathrm{~g}$ $\mathrm{MgSO}_{4} \cdot 7 \mathrm{H}_{2} \mathrm{O}$ and $1.3 \mathrm{~g} \mathrm{CaCl} 2 \cdot 2 \mathrm{H}_{2} \mathrm{O}$ (Bruns et al., 2001). $\mathrm{H}_{2} \mathrm{~S}$ production was tested as described previously (Bruns et al., 2001). Susceptibility to antibiotics was investigated by spreading bacterial suspension on MA and applying paper discs impregnated with the following antibiotics (concentration per disc); ampicillin $(10 \mu \mathrm{g})$, carbenicillin $(100 \mu \mathrm{g})$, cephalothin $(30 \mu \mathrm{g})$, chloramphenicol $(100 \mu \mathrm{g})$, gentamicin $(30 \mu \mathrm{g})$, kanamycin $(30 \mu \mathrm{g})$, lincomycin $(15 \mu \mathrm{g})$, neomycin $(30 \mu \mathrm{g})$, novobiocin $(5 \mu \mathrm{g})$, oleandomycin $(15 \mu \mathrm{g})$, penicillin $\mathrm{G}(20 \mathrm{U})$, polymyxin B $(100 \mathrm{U})$, streptomycin $(50 \mu \mathrm{g})$ and tetracycline $(30 \mu \mathrm{g})$. Acid production from carbohydrates was tested as described by Leifson (1963). Utilization of various substrates for growth was determined as described by Baumann \& Baumann (1981), using supplementation with $2 \%(\mathrm{v} / \mathrm{v})$ Hutner's mineral salts solution (Cohen-Bazire et al., 1957) and $1 \%(\mathrm{v} / \mathrm{v})$ vitamin solution (Staley, 1968). The carbon sources were added at a concentration of $0.2 \%$ $(\mathrm{w} / \mathrm{v})$ after sterilization by filtration. The API ZYM system (bioMérieux) was used to determine enzyme activities.

Strain $\mathrm{HD}-28^{\mathrm{T}}$ was cultivated at $30{ }^{\circ} \mathrm{C}$ in $\mathrm{MB}$ to obtain the cell biomass required for DNA extraction and for the analyses of isoprenoid quinones and polar lipids. Chromosomal DNA was isolated and purified according to the method described by Yoon et al. (1996), with the exception that RNase T1 was used in combination with RNase A to minimize the contamination of RNA. The $16 \mathrm{~S}$

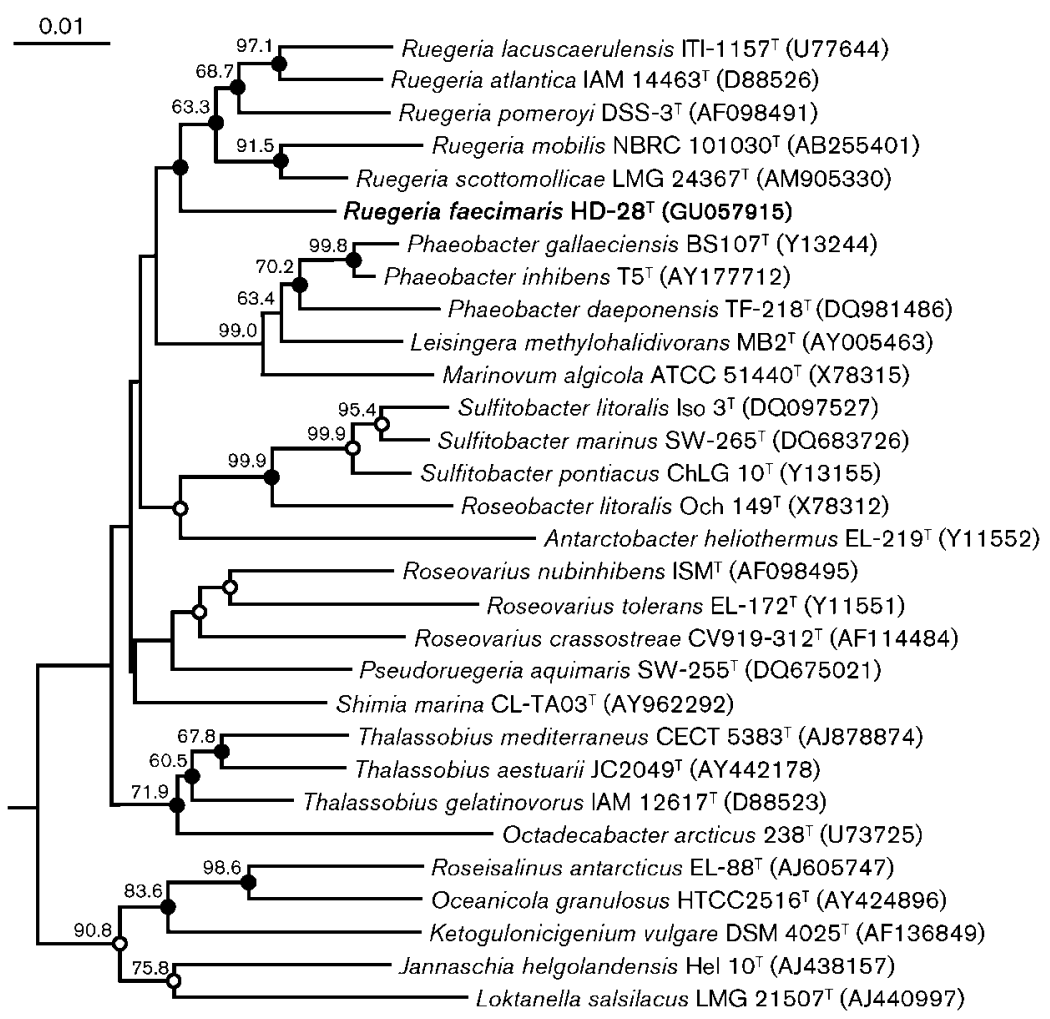

Fig. 1. Neighbour-joining phylogenetic tree based on 16S rRNA gene sequences showing the positions of strain $\mathrm{HD}-28^{\top}$ and some other related taxa. Only bootstrap values (expressed as percentages of 1000 replications) $>50 \%$ are shown at branching points. Filled circles indicate that the corresponding nodes were also recovered in the trees generated with the maximum-likelihood and maximum-parsimony algorithms, while open circles indicate that the corresponding nodes were also recovered in the tree generated with one of these algorithms. Stappia stellulata IAM $12621^{\top}$ (GenBank accession no. D88525) was used as an outgroup (not shown). Bar, 0.01 substitutions per nucleotide position. 
rRNA gene was amplified by PCR using two universal primers as described previously (Yoon et al., 1998). Sequencing of the amplified $16 \mathrm{~S}$ rRNA gene and phylogenetic analyses were performed as described by Yoon et al. (2003). PCR amplification of the gyrB gene was performed by using two primers, UP-1 and UP-2r, according to the method described previously (Yamamoto \& Harayama, 1995). The PCR product was purified with a QIAquick PCR purification kit (Qiagen). The amplified gyrB gene was cloned into pGEM T-easy vector (Promega) according to the manufacturer's instructions. The sequence of the gyrB gene was determined for both strands by extension from vector-specific priming sites (T7 and SP-6 primers from pGEM T-easy). Phylogenetic analysis of gyrB gene sequences was performed as described by Yoon et al. (2007).

Isoprenoid quinones were extracted according to the method of Komagata \& Suzuki (1987) and analysed using reversed-phase HPLC and a YMC ODS-A $(250 \times 4.6 \mathrm{~mm})$ column. Polar lipids were extracted according to the procedures described by Minnikin et al. (1984) and were identified by means of two-dimensional TLC followed by spraying with the appropriate detection reagents (Minnikin et al., 1984; Komagata \& Suzuki, 1987). The presence of phosphatidylcholine was tested by spraying Dragendorff s reagent (Sigma). For cellular fatty acid analysis, cell mass of strain HD-28 ${ }^{\mathrm{T}}, R$. atlantica KCTC $12424^{\mathrm{T}}$, R. lacuscaerulensis KCTC $2953^{\mathrm{T}}, R$. mobilis CIP $109181^{\mathrm{T}}$, R. pomeroyi DSM $15171^{\mathrm{T}}$ and $R$. scottomollicae CCUG $55858^{\mathrm{T}}$ was harvested from MA plates after cultivation for 3 days at $30{ }^{\circ} \mathrm{C}$. The fatty acids were extracted and fatty acid methyl esters were prepared according to the standard protocol of the MIDI/Hewlett Packard Microbial Identification System (Sasser, 1990). The DNA G + C content was determined by the method of Tamaoka \& Komagata (1984) with the modification that DNA was hydrolysed and the resultant nucleotides were analysed by reversed-phase HPLC.

The morphological, cultural, physiological and biochemical characteristics of strain $\mathrm{HD}-28^{\mathrm{T}}$ are given in the species description (see below) and in Table 1. The almostcomplete 16S rRNA gene sequence of strain HD- $28^{\mathrm{T}}$ comprised $1417 \mathrm{nt}$. In the neighbour-joining phylogenetic tree based on $16 \mathrm{~S}$ rRNA gene sequences, strain HD- $28^{\mathrm{T}}$ joined the cluster comprising species of the genus Ruegeria with a bootstrap resampling value of $52.7 \%$ (Fig. 1). The relationship between strain $\mathrm{HD}-28^{\mathrm{T}}$ and the cluster comprising members of the genus Ruegeria was also maintained in trees constructed using the maximumlikelihood and maximum-parsimony algorithms (Fig. 1). Strain HD- $28^{\mathrm{T}}$ exhibited $96.9 \% 16 \mathrm{~S}$ rRNA gene sequence similarity to $R$. scottomollicae LMG $24367^{\mathrm{T}}$ and 95.5$96.4 \%$ similarity to the type strains of the other species of the genus Ruegeria. The gyrB gene sequence of strain HD$28^{\mathrm{T}}$ determined in this study comprised $1177 \mathrm{nt}$. In the neighbour-joining phylogenetic tree based on gyrB gene sequences, strain $\mathrm{HD}-28^{\mathrm{T}}$ fell within the cluster comprising species of the genus Ruegeria (Fig. 2). Strain HD- $28^{\mathrm{T}}$ exhibited $77.5-83.9 \%$ gyrB gene sequence similarity to members of the genus Ruegeria and less than $80.6 \%$ to other species used in this study.

The predominant isoprenoid quinone detected in strain HD- $28^{\mathrm{T}}$ was ubiquinone-10 (Q-10), in line with other

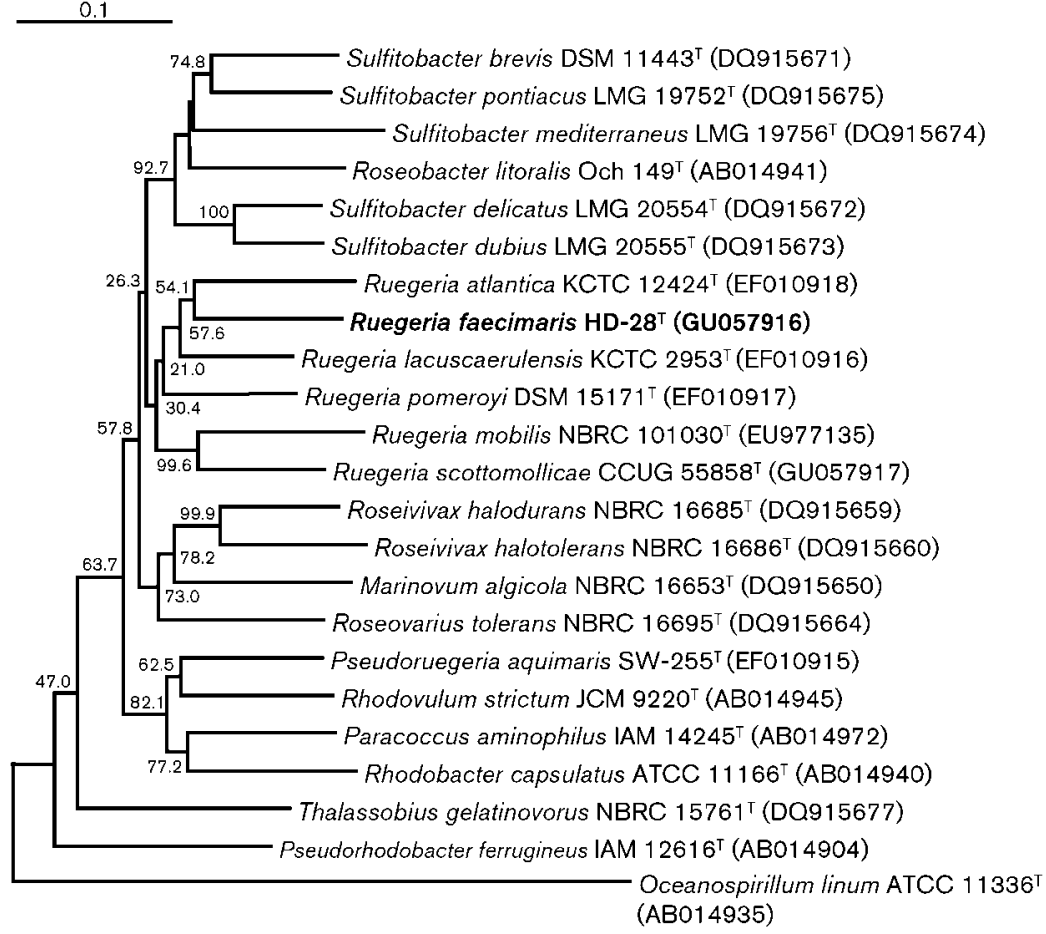

http://ijs.sgmjournals.org
Fig. 2. Neighbour-joining phylogenetic tree based on gyrB gene sequences showing the positions of strain $\mathrm{HD}-28^{\top}$ and some other related taxa. Bootstrap values (expressed as percentages of 1000 replications) are shown at branch points. Oceanospirillum linum ATCC $11336^{\top}$ (GenBank accession no. AB014935) was used as an outgroup. Bar, 0.1 substitutions per nucleotide position. 
members of the genus Ruegeria (Yi et al., 2007; Muramatsu et al., 2007). The fatty acid profile of strain $\mathrm{HD}-28^{\mathrm{T}}$ is shown in Table 2, together with those of the type strains of members of the genus Ruegeria also analysed in this study. The major fatty acid found in strain $\mathrm{HD}-28^{\mathrm{T}}$ was $\mathrm{C}_{18: 1} \omega 7 \mathrm{c}$ (Table 2). The fatty acid profile of strain $\mathrm{HD}-28^{\mathrm{T}}$ was similar to those of the type strains of species of the genus Ruegeria, even though there were differences in the proportions of some fatty acids (Table 2 ). The major polar lipids detected in strain $\mathrm{HD}-28^{\mathrm{T}}$ were phosphatidylcholine, phosphatidylglycerol, an unidentified aminolipid and two unidentified lipids; a minor amount of diphosphatidylglycerol was also detected (Fig. 3). The DNA G + C content for strain $\mathrm{HD}-28^{\mathrm{T}}$ was $57.9 \mathrm{~mol} \%$. The results obtained from the chemotaxonomic analyses supported the results from the phylogenetic analysis based on 16S rRNA gene sequences, suggesting that strain $\mathrm{HD}-28^{\mathrm{T}}$ belonged to the genus Ruegeria.

Strain HD- $28^{\mathrm{T}}$ was clearly distinguishable from recognized species of the genus Ruegeria by differences in several phenotypic characteristics, including hydrolysis and utilization of, and acid production from certain substrates, most of which were determined using the same methods in this study (Table 1). Phylogenetic distinctiveness, together with differential phenotypic properties, was sufficient to

Table 2. Cellular fatty acid compositions (\%) of strain HD-28 ${ }^{\top}$ and the type strains of species of the genus Ruegeria

Strains: $1, \mathrm{HD}-28^{\mathrm{T}} ; 2$, R. atlantica KCTC $12424^{\mathrm{T}} ; 3$, R. lacuscaerulensis KCTC $2953^{\mathrm{T}}$; 4, R. mobilis CIP $109181^{\mathrm{T}}$; 5, R. pomeroyi DSM $15171^{\mathrm{T}}$; 6, R. scottomollicae CCUG $55858^{\mathrm{T}}$. All data are from this study. Fatty acids that represented $<0.5 \%$ in all strains were omitted. -, Not detected.

\begin{tabular}{|lcccccc|}
\hline Fatty acid & $\mathbf{1}$ & $\mathbf{2}$ & $\mathbf{3}$ & $\mathbf{4}$ & $\mathbf{5}$ & $\mathbf{6}$ \\
\hline Straight-chain fatty acid & & & & & & \\
$\mathrm{C}_{10: 0}$ & 3.1 & 2.6 & 6.3 & - & 2.8 & - \\
$\mathrm{C}_{12: 0}$ & 3.4 & 3.1 & 4.5 & - & 1.2 & 0.1 \\
$\mathrm{C}_{16: 0}$ & 4.4 & 3.6 & 1.8 & 5.3 & 8.2 & 2.5 \\
$\mathrm{C}_{18: 0}$ & 0.7 & 0.6 & 2.0 & 1.5 & 2.0 & 0.6 \\
Unsaturated fatty acid & & & & & & \\
$\mathrm{C}_{17: 1} \omega 7 c$ & - & - & - & 0.5 & 0.4 & 1.0 \\
$\mathrm{C}_{18: 1} \omega 7 c$ & 73.6 & 63.5 & 69.8 & 74.1 & 66.7 & 79.1 \\
$\mathrm{C}_{20: 1} \omega 7 c$ & - & 0.3 & 0.8 & 0.3 & 0.4 & 0.3 \\
Hydroxy fatty acid & & & & & & \\
$\mathrm{C}_{10: 0} 3-\mathrm{OH}$ & 0.9 & 0.5 & 3.3 & 3.2 & 0.6 & 2.8 \\
$\mathrm{C}_{12: 0} 3-\mathrm{OH}$ & 4.8 & 5.2 & 7.5 & 0.8 & 6.1 & 0.3 \\
$\mathrm{C}_{16: 0} 2-\mathrm{OH}$ & 3.9 & 6.9 & - & 5.9 & 5.2 & 4.3 \\
$\mathrm{C}_{18: 1} 2-\mathrm{OH}$ & 1.1 & 1.2 & - & 1.1 & 0.2 & 3.0 \\
11 methyl C $_{18: 1} \omega 7 c$ & 2.1 & 11.3 & 1.8 & 4.2 & 5.4 & 2.5 \\
Cyclo C $19: 0 \omega 8 c$ & - & - & 0.6 & - & - & - \\
Unknown fatty acid $^{*}$ & & & & & & \\
ECL 11.799 & 0.3 & 0.2 & 1.2 & 3.0 & 0.1 & 2.5 \\
& & & & & & \\
\hline
\end{tabular}

${ }^{\star}$ ECL, Equivalent chain-length.

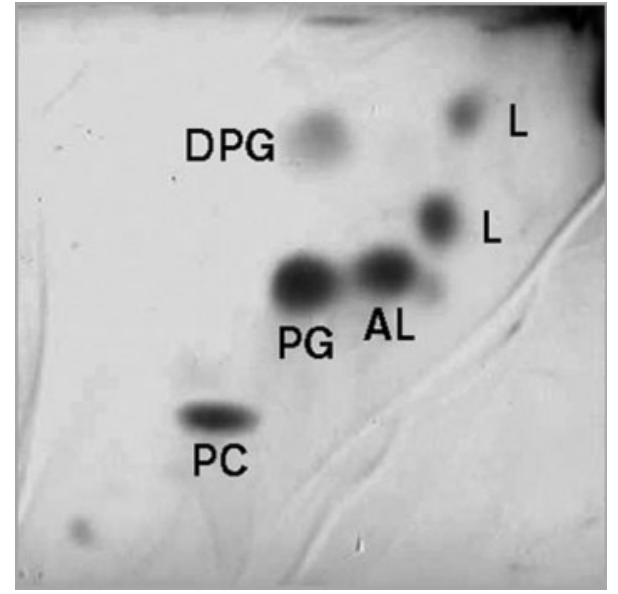

Fig. 3. TLC chromatogram of polar lipids of strain $H D-28^{\top} . P C$, phosphatidylcholine; PG, phosphatidylglycerol; DPG, diphosphatidylglycerol; $A L$, unidentified aminolipid; $L$, unidentified lipid.

allocate strain $\mathrm{HD}-28^{\mathrm{T}}$ as a species distinct from recognized species of the genus Ruegeria (Stackebrandt \& Goebel, 1994). Therefore, on the basis of the data presented, strain HD- $28^{T}$ is considered to represent a novel species of the genus Ruegeria, for which the name Ruegeria faecimaris sp. nov. is proposed.

\section{Description of Ruegeria faecimaris sp. nov.}

Ruegeria faecimaris (fae.ci.ma'ris. L. n. faex faecis sediment; L. gen. n. maris of the sea; N.L. gen. n. faecimaris of the sediment of the sea).

Cells stain Gram-negative, are non-motile and rod-shaped. Cells are $0.3-0.6 \times 1.0-8.0 \mu \mathrm{m}$; a few cells longer than $10.0 \mu \mathrm{m}$ may occur. Colonies on MA are circular, glistening, convex, smooth, greyish yellow in colour and $0.5-2.0 \mathrm{~mm}$ in diameter after incubation for 5 days at $30{ }^{\circ} \mathrm{C}$. Growth occurs at 4 and $37{ }^{\circ} \mathrm{C}$, but not at $40{ }^{\circ} \mathrm{C}$. Optimal $\mathrm{pH}$ for growth is between 7.0 and 8.0; growth occurs at $\mathrm{pH} 5.0$, but not at $\mathrm{pH} 4.5$. Growth occurs in the presence of $7.0 \%(\mathrm{w} / \mathrm{v}) \mathrm{NaCl}$, but not in the absence of $\mathrm{NaCl}$ or in the presence of more than $8.0 \%(\mathrm{w} / \mathrm{v}) \mathrm{NaCl}$. Hypoxanthine, L-tyrosine and Tweens 20, 40, 60 and 80 are hydrolysed and aesculin is weakly hydrolysed, but casein, gelatin, starch, urea and xanthine are not hydrolysed. Cellobiose, D-fructose, D-galactose, D-glucose, D-mannose, acetate, citrate, L-malate, pyruvate and succinate are utilized as carbon and energy sources, but L-arabinose, maltose, sucrose, trehalose, D-xylose, benzoate, formate, salicin, L-glutamate are not utilized. Acid is produced from D-galactose, L-rhamnose, D-ribose and sucrose, but not from L-arabinose, cellobiose, D-fructose, D-glucose, myoinositol, lactose, maltose, D-mannitol, D-mannose, melezitose, melibiose, raffinose, D-sorbitol, trehalose or D-xylose. Susceptible to ampicillin, carbenicillin, cephalothin, chloramphenicol, gentamicin, kanamycin, neomycin, penicillin 
G, polymyxin B and streptomycin, but not to lincomycin, novobiocin, oleandomycin or tetracycline. In assays with the API ZYM system, alkaline phosphatase and acid phosphatase are present and esterase (C4) is weakly present, but esterase lipase (C8), lipase (C14), leucine arylamidase, valine arylamidase, cystine arylamidase, trypsin, $\alpha$-chymotrypsin, naphthol-AS-BI-phosphohydrolase, $\alpha$-galactosidase, $\beta$-galactosidase, $\beta$-glucuronidase, $\alpha$-glucosidase, $\beta$-glucosidase, $N$-acetyl- $\beta$-glucosaminidase, $\alpha$-mannosidase and $\alpha$-fucosidase are absent. The predominant ubiquinone is Q-10. The major fatty acid ( $>10 \%$ of total fatty acids) is $\mathrm{C}_{18: 1} \omega 7 c$. The major polar lipids are phosphatidylcholine, phosphatidylglycerol, an unidentified aminolipid and two unidentified lipids. The DNA G + C content of the type strain is $57.9 \mathrm{~mol} \%$ (determined by HPLC).

The type strain, HD- $28^{\mathrm{T}} \quad\left(=\mathrm{KCTC} \quad 23044^{\mathrm{T}}=\mathrm{CCUG}\right.$ $58878^{\mathrm{T}}$ ), was isolated from a tidal flat of Hwang-do, Korea.

\section{Acknowledgements}

This work was supported by the 21C Frontier Program of Microbial Genomics and Applications (grant MG05-0401-2-0) and the Program for Collection, Management and Utilization of Biological Resources (grant M10867010003) from the Ministry of Education, Science \& Technology (MEST) of the Republic of Korea.

\section{References}

Arahal, D. R., Macián, M. C., Garay, E. \& Pujalte, M. J. (2005). Thalassobius mediterraneus gen. nov., sp. nov., and reclassification of Ruegeria gelatinovorans as Thalassobius gelatinovorus comb. nov. Int J Syst Evol Microbiol 55, 2371-2376.

Arahal, D. R., Macián, M. C., Garay, E. \& Pujalte, M. J. (2006). Thalassobius gelatinovorus comb. nov. In List of New Names and New Combinations Previously Effectively, but not Validly, Published, Validation List no. 107. Int J Syst Evol Microbiol 56, 1-6.

Baumann, P. \& Baumann, L. (1981). The marine Gram-negative eubacteria: genera Photobacterium, Beneckea, Alteromonas, Pseudomonas, and Alcaligenes. In The Prokaryotes, pp. 1302-1331. Edited by M. P. Starr, H. Stolp, H. G. Trüper, A. Balows \& H. G. Schlegel. Berlin: Springer.

Bruns, A., Rohde, M. \& Berthe-Corti, L. (2001). Muricauda ruestringensis gen. nov., sp. nov., a facultatively anaerobic, appendaged bacterium from German North Sea intertidal sediment. Int J Syst Evol Microbiol 51, 1997-2006.

Cohen-Bazire, G., Sistrom, W. R. \& Stanier, R. Y. (1957). Kinetic studies of pigment synthesis by nonsulfur purple bacteria. J Cell Comp Physiol 49, 25-68.

Cowan, S. T. \& Steel, K. J. (1965). Manual for the Identification of Medical Bacteria. London: Cambridge University Press.

González, J. M., Covert, J. S., Whitman, W. B., Henriksen, J. R., Mayer, F., Scharf, B., Schmitt, R., Buchan, A., Fuhrman, J. A. \& other authors (2003). Silicibacter pomeroyi sp. nov. and Roseovarius nubinhibens sp. nov., dimethylsulfoniopropionate-demethylating bacteria from marine environments. Int J Syst Evol Microbiol 53, 1261-1269.

Komagata, K. \& Suzuki, K. (1987). Lipids and cell-wall analysis in bacterial systematics. Methods Microbiol 19, 161-207.
Lai, Q., Yuan, J., Li, F., Zheng, T. \& Shao, Z. (2010). Ruegeria pelagia is a later heterotypic synonym of Ruegeria mobilis. Int $J$ Syst Evol Microbiol 60, 1918-1920.

Lányí, B. (1987). Classical and rapid identification methods for medically important bacteria. Methods Microbiol 19, 1-67.

Lee, K., Choo, Y.-J., Giovannoni, S. J. \& Cho, J.-C. (2007). Ruegeria pelagia sp. nov., isolated from the Sargasso Sea, Atlantic Ocean. Int J Syst Evol Microbiol 57, 1815-1818.

Leifson, E. (1963). Determination of carbohydrate metabolism of marine bacteria. J Bacteriol 85, 1183-1184.

Martens, T., Heidorn, T., Pukall, R., Simon, M., Tindall, B. J. \& Brinkhoff, T. (2006). Reclassification of Roseobacter gallaeciensis RuizPonte et al. 1998 as Phaeobacter gallaeciensis gen. nov., comb. nov., description of Phaeobacter inhibens sp. nov., reclassification of Ruegeria algicola (Lafay et al. 1995) Uchino et al. 1999 as Marinovum algicola gen. nov., comb. nov., and emended descriptions of the genera Roseobacter, Ruegeria and Leisingera. Int J Syst Evol Microbiol 56, 1293-1304.

Minnikin, D. E., O'Donnell, A. G., Goodfellow, M., Alderson, G., Athalye, M., Schaal, A. \& Parlett, J. H. (1984). An integrated procedure for the extraction of bacterial isoprenoid quinones and polar lipids. J Microbiol Methods 2, 233-241.

Muramatsu, Y., Uchino, Y., Kasai, H., Suzuki, K. \& Nakagawa, Y. (2007). Ruegeria mobilis sp. nov., a member of the Alphaproteobacteria isolated in Japan and Palau. Int J Syst Evol Microbiol 57, 1304-1309.

Petursdottir, S. K. \& Kristjansson, J. K. (1997). Silicibacter lacuscaerulensis gen. nov., sp. nov., a mesophilic moderately halophilic bacterium characteristic of the Blue Lagoon geothermal lake in Iceland. Extremophiles 1, 94-99.

Rüger, H.-J. \& Höfle, M. G. (1992). Marine star-shaped-aggregateforming bacteria: Agrobacterium atlanticum sp. nov.; Agrobacterium meteori sp. nov.; Agrobacterium ferrugineum sp. nov., nom. rev.; Agrobacterium gelatinovorum sp. nov., nom. rev.; and Agrobacterium stellulatum sp. nov., nom. rev. Int J Syst Bacteriol 42, 133-143.

Sasser, M. (1990). Identification of bacteria by gas chromatography of cellular fatty acids, MIDI Technical Note 101. Newark, DE: MIDI Inc.

Stackebrandt, E. \& Goebel, B. M. (1994). Taxonomic note: a place for DNA-DNA reassociation and 16S rRNA sequence analysis in the present species definition in bacteriology. Int J Syst Bacteriol 44, 846849.

Staley, J. T. (1968). Prosthecomicrobium and Ancalomicrobium: new prosthecate freshwater bacteria. J Bacteriol 95, 1921-1942.

Tamaoka, J. \& Komagata, K. (1984). Determination of DNA base composition by reversed-phase high-performance liquid chromatography. FEMS Microbiol Lett 25, 125-128.

Uchino, Y., Hirata, A., Yokota, A. \& Sugiyama, J. (1998). Reclassification of marine Agrobacterium species: Proposals of Stappia stellulata gen. nov., comb. nov., Stappia aggregata sp. nov., nom. rev., Ruegeria atlantica gen. nov., comb. nov., Ruegeria gelatinovora comb. nov., Ruegeria algicola comb. nov., and Ahrensia kieliense gen. nov., sp. nov., nom. rev. J Gen Appl Microbiol 44, 201210.

Vandecandelaere, I., Nercessian, O., Segaert, E., Achouak, W., Faimali, M. \& Vandamme, P. (2008). Ruegeria scottomollicae sp. nov., isolated from a marine electroactive biofilm. Int J Syst Evol Microbiol 58, 2726-2733.

Yamamoto, S. \& Harayama, S. (1995). PCR amplification and direct sequencing of $g y r B$ genes with universal primers and their application to the detection and taxonomic analysis of Pseudomonas putida strains. Appl Environ Microbiol 61, 1104-1109. 
Yi, H., Lim, Y. W. \& Chun, J. (2007). Taxonomic evaluation of the genera Ruegeria and Silicibacter: a proposal to transfer the genus Silicibacter Petursdottir and Kristjansson 1999 to the genus Ruegeria Uchino et al. 1999. Int J Syst Evol Microbiol 57, 815819.

Yoon, J.-H., Kim, H., Kim, S.-B., Kim, H.-J., Kim, W. Y., Lee, S. T., Goodfellow, M. \& Park, Y.-H. (1996). Identification of Saccharomonospora strains by the use of genomic DNA fragments and rRNA gene probes. Int J Syst Bacteriol 46, 502-505.
Yoon, J.-H., Lee, S. T. \& Park, Y.-H. (1998). Inter- and intraspecific phylogenetic analysis of the genus Nocardioides and related taxa based on 16S rDNA sequences. Int J Syst Bacteriol 48, 187-194.

Yoon, J.-H., Kang, K. H. \& Park, Y.-H. (2003). Psychrobacter jeotgali sp. nov., isolated from jeotgal, a traditional Korean fermented seafood. Int J Syst Evol Microbiol 53, 449-454.

Yoon, J.-H., Lee, S. Y., Kang, S. J., Lee, C. H. \& Oh, T. K. (2007), Pseudoruegeria aquimaris gen. nov., sp. nov., isolated from seawater of the East Sea in Korea. Int J Syst Evol Microbiol 57, 542-547. 